\title{
Fiber Device
}

National Cancer Institute

\section{Source}

National Cancer Institute. Fiber Device. NCI Thesaurus. Code C49952.

Any device made from a long, slender material. 